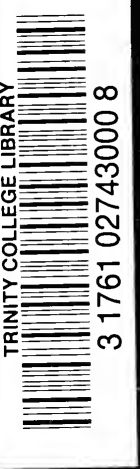

TWE STORY OF THE REVISION OF THE IRISR PRAYER BOOK.

VENERABLE WILLIAM SHERLOCK, H.A. 


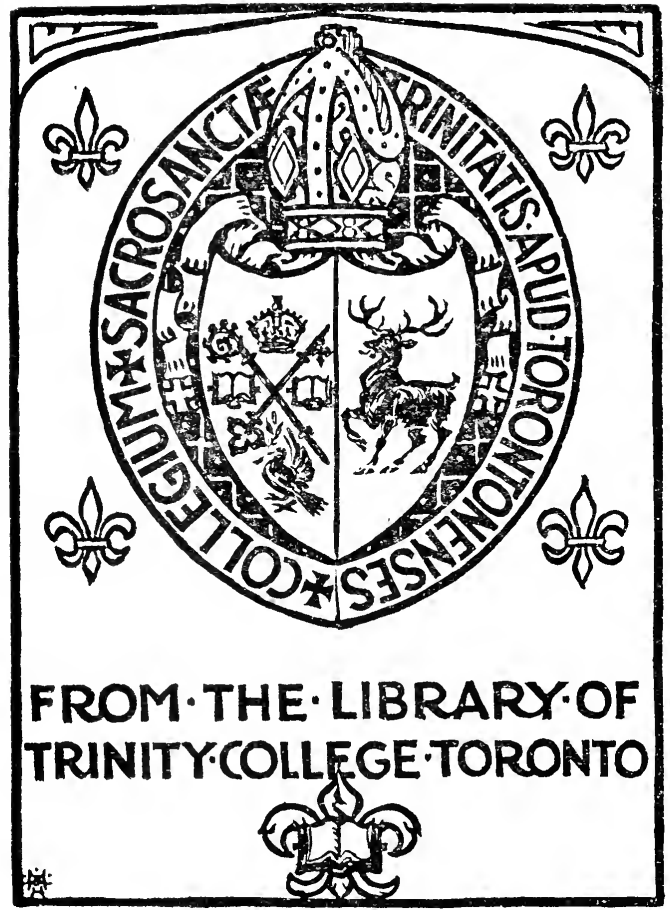



A.R D.F ïhay

miven Polutum 


\title{
THE STORY OF THE REVISION
}

OF THE

\section{IRISH PRAYER BOOK.}

\author{
BY THE \\ VENERABLE WILLIAM SHERLOCK, M.A., \\ Archdeacon of Kildare.
}

[Reprinted from The Irish Church Quarterly.]

छublín :

CHURCH OF IRELAND PRINTING AND PUBLISHING Co., LTD.

6I MIDDLE ABBEY STREET

1910. 
36

10

$12 ? 434$

IAY 111988 


\section{P R E F A C E.}

THE publication of these recollections of the Revision of the Irish Book of Common Prayer originated in a wish expressed by Dr. Dowden, the late Bishop of Edinburgh, that something of the kind should be attempted. They appeared, by desire, in The Irish Church Quarterly, which could grant but a limited space, and this must be the excuse for the omission of much that I would gladly have included. To repair these omissions would entail rearranging, and to a considerable extent re-writing, a task which I do not now feel inclined to undertake. There are few living who passed through those troublesome times, but there may be others to whom the story of a very momentous period in the history of their Church will have an interest, particularly in view of the attempt which is now being made to complete the work of revision on non-controversial lines.

\section{W. SHERLOCK.}

Sherlockstown, Sallins, May, IgIo. 



\section{NOTE :}

IN the remarks on the Baptismal Office it is said, "The wording of the first address was slightly changed by the substitution of one text of St. John for another." This is not quite accurate. My friend the Dean of Kildare has pointed out to me that what was really done was that for an amalgam of two texts from the 3 rd chapter of St. John, headed by the words, "Our Saviour Christ saith," was substituted in the very words of Christ, the two texts on which the amalgam was based. 



\section{The Story of the Revision of the Irish Prayer Book.}

The story of the Prayer Book is in great part the story of successive revisions. It must necessarily be so, for the Church is a living organism, with changing environment and changing wants, and with the power of adapting herself to times and circumstances. At present revision is once more in the air. The bishops at the Lambeth Conference discussed the need of it, and formulated recommendations about it. The Church in Wales stands face to face with disestablishment, and consequently with a revision, and it looms large before the Church of England, greatly needed but greatly dreaded.

It may not be uninteresting, then, to give the plain story of the revision of the Prayer Book in the disestablished Church of Ireland. The years that have passed since 1869-79 may help us to judge more fairly and dispassionately what was then done in a time of stress and excitement. What was then an experiment has passed into history and been tested by experience. We cannot recall the passions of the hour, the hopes and fears that swayed the breasts of the members of a Church, small in numbers, but looking back to ancient days and ancient glories, and mindful that she is part of that great Catholic Church which is in the world the Body of Christ; but though these are past, the history remains, fraught, as all history is, with lessons to those who are wise enough to learn them. 
THE DISESTABLISHMENT.

Before entering upon the history of the revision, it is necessary to tell in a few words something of the disestablishment which preceded it, and made it possible. The Act which, on 26th July, 1869, disestablished the Church of Ireland and seized her endowments, bestowed upon her this blessing, that it set her free to resume her self-government independent of the State.

The blow had fallen suddenly. In a sermon on All Saints' Day, 1867, Archbishop Trench said that there was nothing to fear in the near future. Only five months later he wrote that the Dean of Cork, ${ }^{1}$ who was fresh from England, said that the general feeling there was, "The establishment is certainly gone." So much for political forecasts! The mass of Irish Churchmen would not believe it possible. They had been taught to have such faith in England. They had been called the English Garrison. They relied on the fact that the establishment was guaranteed by the Act of Union. They were even angry when reminded that no Parliament can bind future Parliaments. They conceived that even to admit the possibility was an act of treachery, playing into the hands of the enemy. Nevertheless the impossible happened, and the blow fell on 26th July, I869.

On the 18th of August following, the Archbishops of Armagh and Dublin issued mandates for reassembling the old national synods, which, though long in abeyance, were still in existence, and in the province of Dublin had been actually summoned pro forma for a century and a half. The provincial synods met in a united synod in St. Patrick's Cathedral on I4th September, I869, under the Archbishop of Armagh, and sat for three days. They declared that they had met to repair a breach in their ancient Church, and invited the cooperation of the faithful laity. They decided that in the General Convention about to be held the clergy should be represented by delegates elected in diocesan synods.

${ }^{1}$ W. C. Magee; afterwards Archbishop of York. 
In the meantime, on 3ist August, I869, the laity of the Church met in Dublin by representation, the Earl of Meath in the chair, and presented a requisition to the archbishops, who thereupon convened a lay conference, which met on I2th October, and continued three days in session. The Primate presided on the first day, and the Duke of Abercorn afterwards. At this conference the laity insisted that their representation in synods should be in the proportion of two laymen to one clergyman. The number of representatives for each diocese was also settled.

Of this two-to-one representation and the discussion by which it was determined, Archbishop Trench wrote gloomily: "Nothing could be worse or more ominous than the temper of the lay conference." He admitted afterwards, however, that as the voting was by orders it lost its significance; and as a fact it was never an inconvenience, and prevented all jealousy on the part of the laity.

An organization committee, consisting of the bishops and of clerical and lay representatives from each diocese, was appointed to frame the draft of a constitution for the Church. Thirteen "learned persons," of whom seven were judges, were afterwards invited to assist in its deliberations. Considerable misgivings were felt as to its work. It was scarcely hoped that they would produce a unanimous report. Already Archbishop Trench spoke of the existence of " a malignant hostility to everything Churchlike," and expressed his conviction that "some would have to quit the future Church." This pessimistic forecast was falsified. The committee met on 5 th January, 1870, and sat till 28 th January. It seemed a good omen that at the outset Master Brooke, a pronounced low Churchman, declared against the folly and wickedness of anybody wishing to touch the Prayer Book; and the resulting draft constitution was drawn up on conservative lines. Their report was submitted to the General Convention, consisting of the archbishops 
and bishops and clerical and lay delegates from each diocese, on $15^{\text {th }}$ February, 1870.

During the forty-one days that the Convention sat it enacted standing orders, adopted the Constitution of the Church of Ireland, and passed various statutes. The Constitution set forth:-(I) The sufficiency of Holy Scripture, the maintenance of the three orders of the ministry, and of the doctrines, sacraments, and discipline of the Church, and the witness of the Church against innovations in doctrine and worship. (2) The reception and approval of the Thirty-nine Articles approved by the archbishops and bishops and clergy of Ireland in the synod holden in Dublin in 1634, and of the Book of Common Prayer, administration of the sacraments, and other rites and ceremonies, and the ordinal as approved by the synod of Dublin, 1662. (3) A declaration of communion with the Church of England and all other Christian Churches agreeing in her principles. (4) A declaration that a general synod consisting of archbishops, bishops, and representatives of the clergy and laity shall have legislative and administrative power in the Church.

The adoption of this constitution was of the first importance in relation to the question of revision which afterwards arose. It committed the revisionist party to a repudiation of a desire to alter or modify the doctrines of the Church.

Besides the constitution, the Convention also passed a number of statutes. One of these bore upon the question of revision, and was of such importance that it must be given at some length. It enacted that:

"No modification or alteration shall at any time hereafter be made in the articles, doctrines, rites, rubrics, or, save in so far as they may have been made necessary by the passing of the Irish Church Act, 1869, in the formularies of the Church, unless by a bill duly passed.

" No bill for such purpose shall be introduced except on a resolution passed in full synod, stating the nature of the proposed modification or alteration ; and no such bill or resolution shall be deemed to have passed the House of Representatives except by majorities of not 
less than two-thirds of each order of the said House present and voting on such order or resolution. Provided that any such resolution shall be communicated to every diocesan synod at its meeting next after the session of the General Synod at which such resolution shall have been passed; and no bill for such purpose as aforesaid shall be introduced until one year shall have elapsed after such resolution shall have been commun1cated to the diocesan synods."

This very conservative enactment was most probably drawn up by the experienced judges who sat on the Committee of Organization, and in the crisis of the revision movement it undoubtedly saved the Church of Ireland from most serious changes in her doctrines and formularies. Its effect in this direction was soon perceived ; and on 3 rd May, I87 I, General Dunne proposed to rescind the requirement of a two-thirds majority of each order. His motion was defeated, and so were renewed attempts in 1874 and 1876 .

Notwithstanding, such were the apprehensions of radical changes that Archbishop Trench, in giving a donation of $\mathcal{E} \mathrm{r}$, ooo to the Sustentation Fund and making arrangements for giving $\mathcal{E} \mathrm{I}$, ooo a year to the same Fund, reserved the power of stopping instalments in case things " should go to rack and ruin."' For the same reason the general collection on behalf of the Irish Church which was urged by the Church authorities in England was delayed; and even in I872 the London S.P.C.K. deferred for a time a grant of $\notin 5$, ooo to the Irish Church Fund.

Nevertheless the first session of the Convention had passed off successfully, and the Constitution of the Church had been adopted early in 1870 , when, almost before the session had ended, a storm arose in Dublin which precipitated revision.

THE DEMAND FOR REVISION OF THE PRAYER BOOK.

The reports of the practices and teaching of the ritualistic party in the Church of England, with its real

${ }^{2}$ Letter to T. C. Trench (Life, ii. 130). 
or supposed Romeward tendencies, supported by the fact that many of that school had gone over to the Church of Rome, had created a profound sensation in Ireland. From the position of the Church here as a minority in a country where most of the people were Roman Catholic, and from the inheritance of the traditions of what was called the "Protestant Ascendancy," long fostered for its own political purposes by the English Government, the tendency in the Church of Ireland was naturally towards an exaggerated suspicion and distrust of anything that was not anti-Roman in the extreme. It was impossible that, face to face with the claims of the Church of Rome, the Irish Church should not be strongly Protestant. And the contempt and dislike of the ritualists for the word, their yearning for reunion with Rome, together with the rapid spread of their opinions and their aggressive utterances in England, tended to excite a morbid fear of a similar movement in the Church of Ireland. The apprehension was indeed ill-founded. There were few high Churchmen in Ireland and no ritualistic clergy. Nevertheless, the dread of ritualism gave a strong impulse to a call for the revision of the Prayer Book, and to this was added such ignorance as to distinctive Church teaching on the part of the laity, and of many of the clergy, as made the movement very perilous. In many places a loose and vague preaching of the lowest evangelical type with Calvinistic tendencies prevailed, and, in general, dogmatic teaching of Church doctrine was lacking. This had favoured the spread of the great revival movement, which in 1859 and the years following had loosened the hold of the Church upon her people. Enormous stress was laid upon the phenomena of what was called conversion, which was often only a passing hysterical affection, and this had disparaged and weakened the use of the ordinary means of grace, and belief in their efficacy. It was for the most part in vain that thoughtful men like Professor Salmon and Bishop FitzGerald remonstrated; they were by the enthusiasts looked upon 
as mere unspiritual formalists, opposing the work of the Holy Ghost, and a wave of religious emotion swept over the ranks of the Protestant population.

It will, then, be easily understood that an agitation against the doctrines of baptismal regeneration, the real presence, and confession and absolution, found congenial soil in which to grow, with abundant stimulus from without. And such an agitation developed rapidly in Dublin, where a large part of the professedly Church population was at all times ready to fraternize with dissenters who called themselves good Protestants.

Nothing can more clearly show the smouldering suspicion that was ready to burst into a flame on the slightest provocation than the attack made in the spring of 1870 upon the Rev. L. B. Weldon (now Canon of Salisbury) for putting a harmless manual of preparation for confirmation ${ }^{1}$ into the hands of a servant girl. Her master, one Mr. Maberly, at once made it the ground of a denunciation, and when Archbishop Trench declined to condemn it, the daily press for weeks fanned the flame of indignation, and Maberly became the Protestant hero. The agitation spread through the provinces, and thousands who had never seen the book, and who, if they had seen it, would probably not have found anything in it to blame, were persuaded that there was a plot on foot to introduce Roman Catholic doctrine and all the abuses of the confessional into the Church of Ireland, although, as one of its critics naïvely remarked, there was " not a word in the whole book about confession to a priest." But that, of course, was a proof of its deep designs. One bishop said that the manual under discussion " lacked Protestant honesty and evangelical truth, and was a compound of piety and poison."

The result of the agitation was that numerous protests, and petitions for the revision of the Prayer Book came from vestries throughout the country, and a stronglyworded protest was addressed to the Archbishop of Dublin signed by 429 clergy, 529 noblemen, deputy

${ }^{2}$ Short Prayers, \& c., by Mr. Portal, an English clergyman. 
lieutenants, magistrates, and M.D.s, 2,844 registered vestrymen, and 200 members of Convention. The blank walls of Dublin were chalked over with "Puseyite Trench," and many people avowed their determination to withhold all aid from the Church until a revision of the formularies had been carried out in a manner satisfactory to their doctrinal bias.

The book which it was desired to have revised was in most respects identical with the Book of Common Prayer of the Church of Egland of 1662 . This had been examined by both houses of the Irish Convocation separately, and approved, with the addition of the prayer for the Lord Lieutenant. Subsequently an office for the visitation of prisoners, a bidding prayer, a form of dedication of churches, a form for the expiation of a church desecrated, and another for reconciling converted Papists were added. In 1666 the Irish Act of Uniformity was passed by the Irish Parliament, and received the Royal assent.

\section{MASTER BROOKE'S COMMITTEE.}

The agitation for revision would soon have died a natural death had the Church continued in connexion with the State. But being now set free the extreme low Church party lost no time in emphasizing their Protestantism, and Master Brooke who a few months before had spoken of the folly and wickedness of wishing to touch the Prayer Book, presented a memorial to the General Convention on the second day of its second session, I9th October, I870:-

" Humbly showing that resolutions lately passed at many vestry meetings call for action on the part of the Convention." The Memorialists deprecate " any rash or hasty alteration of the formularies ; but inasmuch as a few passages in the Prayer Book have been made a pretext for the introduction of doctrines and practices altogether at variance with the tenor of that book, and repugnant to the Scriptural principles of our Reformed Church, they pray that a committee may be appointed by the Convention to take the whole matter into careful consideration with a view to the suggestion of a remedy, 
and that it be instructed to make its report to the General Synod of $1871 . "$

Archbishop Trench hoped that the synod would throw out the proposal "by a large majority of clergy, and possibly by a small one of laity."' He was disappointed. A motion proposed on 25th October, and amended by the Duke of Abercorn, was carried on $27^{\text {th }}$ October, in the following terms:-

"That a committee be appointed to consider whether without making any such alterations in the liturgy or formularies of our Church as would involve or imply a change in her doctrines, any measure can be suggested calculated to check the introduction and spread of novel doctrines and practices opposed to the principles of our Reformed Church, and to report to the synod in $1871 . "$

This did not satisfy the extreme party, and they proposed that the synod should declare:-

"That we hereby disown and reject the dogmas of the real presence of the body and blood of Christ in the sacrament, priestly absolution, auricular confession, and any necessary connexion between regeneration and baptism."

The amended motion of Master Brooke was however carried without a division.

A week afterwards Master Brooke named his committee which consisted of thirteen clergymen and thirteen laymen. Very few of the clerical members named could claim to be considered theologians of more than moderate attainments; and of the laymen, with the exception of a few legal members, most were country gentlemen guiltless of any knowledge of the questions to be discussed. The principal work of the committee seems to have been done by Dr. Reichel, afterwards Bishop of Meath, the Rev. the Hon. W. C. Plunket, afterwards Archbishop of Dublin, Sir Joseph Napier, and Master Brooke.

It had been intended that the bishops should act on the committee, but on the day it was named the bishops, who had unanimously disapproved of its appointment, announced their decision that, as it would be their duty

${ }^{2}$ Life, ii. 128. 
to give a united and unprejudiced consideration to the report of the committee, it was not expedient that any of their body should take part in its proceedings.

The following instruction to the committee was proposed :-

"To draft a bill to be brought into the first meeting of the General Synod of I87r, which shall declare the doctrines of the Church of Ireland on the subjects of the real presence, auricular confession, and priestly absolution."

This would have given the committee full power to define, and indeed to alter, the doctrine of the Church on these points. It was rejected, the voting being, of the clergy 84 to 13 , and of the laity 59 for and 59 against.

A very serious consequence of the appointment of Master Brooke's committee was that the Archdeacon of Dublin, Dr. Lee, wrote on 3 rd November to resign his position in the Convention, and thereafter took no part in the Convention or in the subsequent General Synods. This was a great blow to the conservative party, as Dr. Lee was known as a theologian of learning, whose work on inspiration enjoyed a considerable reputation in England. The Church of Ireland thus not only lost the advantage of his ability and learning in the revision debates, but was prejudiced in the eyes of English Churchmen by his refusal to acknowledge or take part in her synods. It was a particular grief to the Archbishop of Dublin, who considered that his withdrawal was "quite premature, and a mistake." On the same day Dr. Reichel, in order to remove the bad impression caused by this resignation, proposed the following resolution :-

"That in accepting the resignation of the Archdeacon of Dublin, the Convention distinctly repudiates the allegation contained in his letter of 28 th October to the Lord Primate, viz., 'that the Convention has adopted a resolution, the object of which is to alter or modify the doctrines of the Church, as defined in the Book of Common Prayer." 
The extreme revisionists were unwilling to repudiate an intention to alter or modify doctrine, but they were defeated by 200 to 12 .

The well-known Dr. Maturin, incumbent of All Saints', Grangegorman, a high Churchman of great ability and piety, had unfortunately from the first refused to act under the conditions of disestablishment, and his defection was another heavy discouragement to conservative Churchmen.

In opposing Master Brooke's motion the venerable Astronomer-Royal, Romney Robinson, and the Bishop of Ossory made two powerful speeches, afterwards published by Judge Warren, with a preface supporting their arguments. Dr. Robinson warned the Convention that in no instance has the introduction of heresy and corruption been prevented by any precision of formularies. He asserted that ritualism must be prevented not by altering the formularies, but by means of disciplinary canons. He also urged the danger of injuring the devotional character of the liturgy by alteration, and the further danger of cutting the Eucharist down below the level of a sacrament. O'Brien, the Bishop of Ossory, said that in the general dread of ritualism and Romanism, a nearer danger was overlooked, lest the Church herself should be converted from a tolerant and comprehensive Church into a narrow and exclusive sect. He reminded the Convention that whether the Church was a sect or not depended more upon its principles than its numbers. This disaster might be produced without any alteration of our articles, services, and rubrics, merely by authoritative definitions or explanations, limiting strictly to one sense phrases or words in any of them which have been heretofore regarded as admitting legitimately of some variety of interpretation, so as to leave room in the Church for those who entertained different views upon certain doctrines. No caution could have been more timely or more needed, but no heed was given to it by the party intent on action. 
The first General Synod met on i3th April, I87I, and two days after its opening the report of Master Brooke's committee was presented in I3I pages. After reminding the synod that it had only been appointed to suggest measures to check the introduction and spread of ritualism, it proceeded, with this end, to recommend:

I. An addition to the Black Rubric to the effect that ' no adoration whatever is to be done to any presence of Christ, or of Christ's flesh and blood, supposed to be in the elements after or by virtue of their consecration.

2. A new question and answer in the Catechism, stating that 'Christ's body and blood are taken and received in the Lord's Supper only after a heavenly and spiritual manner, and that the mean whereby they are taken and received is faith.'

3. The omission of the Absolution in the office of the Visitation of the Sick and instead of it the use of 'a prayer of absolution at the priest's discretion.'

4. That in the Ordinal the existing words of ordination should be replaced by a precatory form.

These recommendations were afterwards incorporated in the report of Dr. Salmon's Revision Committee which will come under our notice later on. They were accompanied by arguments in their support, and by an appendix of papers on various subjects connected with them contributed by members of the committee. The bulk of this work was done by Dr. Reichel. Eight members of the committee dissented from the proposed change in the ordinal.

The first recommendation, brought forward in the Synod on 2oth April, was the one to which the least objection was likely to be felt, viz., the additional question and answer in the catechism. It was thrown out by the clergy by iI 7 votes to 79 , but the laymen supported it by 272 to 35 . It was probably thrown out from a perception that the whole question of revision was impending, and from an objection to treating it piecemeal. Still the overwhelming majority of laymen in its favour was an ominous warning to the conservatives. 


\section{DR. SALMON'S REVISION COMMITTEE.}

On 25th April Master Brooke moved, and Lord James Butler seconded, the proposed addition to the Black Rubric. The debate was adjourned on the motion of Judge Warren, in seconding which Dr. Salmon (the Regius Professor of Divinity) made a speech which brought up the subject of a complete revision of the Prayer Book. He urged that "bit by bit" revision could not be satisfactory, and that though the time had come for a complete revision of the formularies in a cautious and reverent spirit, it was not advisable to consider separately isolated alterations, and he advised that the bishops be requested, in conjunction with a committee to be named from among the representative members of the synod, to consider the whole subject of revision, and report on it to the synod of 1872 . He represented that the division on the first recommendation of Master Brooke's committee showed that there was no chance of carrying all its proposals in that synod, though he admitted the significance of the vote of the laity. He urged that revision was not only lawful, but that it was expedient and absolutely unavoidable.

" Our choice," he said, " is whether the revision shall be conducted by our bishops and the most trusted men in the synod sitting calmly in committee, or in full synod as the fancy of any individual member may suggest to him to bring up particular parts of the Prayer Book for revision. It should be done," he went on, " not in full House, but in a committee, and of that committee it is essential that the bishops should take the lead. It were an unheard of thing if a company of presbyters and laymen were to draw up a series of liturgical reforms, and tender them to the bishops for acceptance or rejection. Moreover the committee must not be onesided. The party of change and the party hitherto opposed to change must be fully and fairly represented. . . The report of the committee would be worthless if it were carried by a narrow majority. If, when it shall have been drawn up and carried even by a large majority, half a dozen members, such as I could easily name, were to protest and say, "These alterations are such as we cannot with a good conscience consent to,' 
the work of the committee must be pronounced a failure, and their report would not be worth the paper it might be printed on."

This speech produced a deep impression upon the synod.

When the debate on the proposed addition to the Black Rubric was resumed on 28th April, the Lord Primate read a statement from the archbishops and bishops in reply to the request that they would take part in a committee of revision such as Dr. Salmon suggested. This reply stated that they accepted Master Brooke's assurance that, in the event of their consenting, he would do his best to induce the synod to permit him to withdraw for the present year the recommendations of his committee, and would resist all discussions upon doctrine during the present synod. Upon this and upon the understanding that the synod would enter upon revision, not as seeking to amend error, but as willing to try "whether what is good already might not be made better still," the archbishops and bishops consented to act.

Dr. Salmon's motion for a revision committee was then passed, the number of the committee exclusive of the bishops being fixed at twenty-two clerical and eighteen lay members. On 4th May the names of members selected were put to the synod by the chairman, Dr. Butcher, Bishop of Meath, and approved, with the exception of a few who were suspect as moderate high Churchmen. The vacant places were afterwards filled by vote.

On 8th May it was proposed as an instruction to the Revision Committee,

" to exclude effectually from the Church of Ireland the teaching and observance of the doctrines of baptismal regeneration, the real and essential objective presence, sacerdotal absolution, and other doctrines and practices opposed to the Protestant principles of the Reformation."

This was rejected by I I 2 to 30 .

Two days after, on Ioth May, the Revision Committee met in the house of the Representative Church Body, 
and after electing secretaries, fixing a quorum, and doing some other formal business, adjourned to $4^{\text {th }}$ October, in order, in the meantime, to receive suggestions.

By the appointment of the Revision Committee the Prayer Book was taken out of the hands of the synod until the committee should report in the following year, but the disciplinary canons recommended by Master Brooke's committee to guard against ritualism remained for consideration, and they were taken up when the other canons were being passed in review.

THE PRINCIPAL LEADERS IN THE DEBATES ON REVISION.

Before entering on the immediate story of the revision let us glance for a moment at some of the leading members of the synod who took part in the debates.

Few of them now remain to visit the scene where once they were accustomed to meet-where so many friendships were formed, and opponents learned to respect and even love one another. The once familiar faces are absent, the well-known voices are silent. Now they are little more than a rapidly vanishing memory. Still, those who survive recall with surprise and admiration the absorbing interest and high level of the debates, and the wonderful earnestness with which even laymen who at first were utterly inexperienced in the subjects under discussion devoted themselves to their study. It pleased Canon Liddon once to sneer at what he called a singular assembly of country squires, colonels, and lawyers, but had he listened to the debates, much as he abhorred the idea of laymen taking part in or voting upon such matters, he must have learned that they deserved respect and not contempt.

Marcus Gervais Beresford, Primate of All Ireland and Archbishop of Armagh, was president of the synod. He came of a family which had long held high rank in the Church of Ireland, and therein had acquired great wealth. His predecessor in the see, a member of the 
same family, had been called for his good looks "the Beauty of Holiness," and he himself was little less remarkable in that respect. Tall, erect, and aristocratic in appearance, he bore his considerable years well. With a telling voice, a ready wit, great knowledge of the world, and an unfailing temper, he made an admirable president.

Next to him came Richard Chenevix Trench, sometime a revolutionist in Spain, later Dean of Westminster, and finally Archbishop of Dublin; the friend of John Keble, W. B. Donne, John Sterling, Arthur Hallam, F. D. Maurice, Bishop S. Wilberforce, Liddon, Church, Pusey, and other remarkable men. His massive intellectual head and fine brow betokened him a scholar and a poet, with a touch of romanticism in his composition. Of shorter build than the Primate, and younger, he was less worldly wise, and more spiritually minded-too sensitive to bear well the strain of conflict, and the roughness of a popular assembly, but easily stirred to a holy indignation at the suggestion of anything mean or base. His poetic temperament was tinged with the melancholy which in later years marked his habitual expression, though his face would occasionally light up with a smile when his Irish sense of humour was touched. He was the soul of honour, gentle, tender, and true; many a time must he have looked back to Westminster with regret, when he felt himself in the toils of the Philistines of the synod hall. In Dublin he was little understood or appreciated.

Next in distinction to these was FitzGerald, Bishop of Killaloe, who was of the best type of the broad Church school. Learned, moderate, and wise, he was probably the best theologian, and certainly the ablest bishop on the bench, in spite of a besetting indolence which provoked those who knew him best. He looked, and might have been, an Erasmus risen from the dead.

In strangest contrast to him was John Gregg, Bishop of Cork, once a well-known popular preacher. There was little of formal theology in his picturesque and 
alliterative eloquence, but he could address the Celtic portion of his diocese in their own beloved Irish. Beside these sat Butcher, Bishop of Meath, ex-Regius Professor of Divinity in the University of Dublin, learned and profoundly cautious; Graves, Bishop of Limerick, a scholar and an antiquarian, whose frail form scarcely promised that he would attain the allotted portion of three score years and ten. With them may be numbered Knox, Bishop of Down, who had strong common sense, and knowledge of men, and who succeeded Beresford in the see of Armagh.

Last, and perhaps best loved of all, William Alexander, then Bishop of Derry, now, in his 85th year, Archbishop of Armagh; a poet and orator, the magic of whose magnificent voice and splendid eloquence in pulpit and in the synod so often held men spellbound.

Among the most prominent of the laymen who were anxious to revise the Book of Common Prayer and to purge out what they called its leaven of Romanism, was Lord James Butler, uncle of the Marquis of Ormonde. Rather past middle age, handsome and of a noble and commanding presence, a connoisseur and lover of art, with a fine voice and admirable delivery, he was formidable in debate. His power of sarcasm was considerable, and for some reason he made the bishops, and in particular Archbishop Trench, the mark for his most bitter attacks. However, upon one curious occasion he made honourable amends. There had been a slight scene in the synod between him and the Archbishop, and Mr. Disraeli had taken advantage of it to point some of his remarks in the House of Commons by announcing that Archbishop Trench had been "excommunicated by an assembly of Irish Protestants." Lord James Butler on the first opportunity rose in the synod to move a resolution repudiating in the strongest terms such a statement as an insult to the synod, and expressing the respect in which they held the Archbishop and their hope that he might long preside over them. This, of course, was carried by acclamation, and doubtless greatly amused the "eminent statesman." 
Charles Parsons Reichel, then a country clergyman, afterwards Bishop of Meath, was another fervent revisionist. His bitter tongue did not belie the expression of his face. He had a keen appreciation of his superior learning, and he was indeed the best learned of his party. He found a foe worthy of his steel in Richard Travers Smith, a sound Churchman and a really learned theologian, though not a brilliant speaker, who by sheer weight of superior knowledge, earnestness, and absolute sincerity claimed and won the attention and respect of those who were most opposed to what they considered his high Church proclivities. Next to him on the conservative side must be reckoned Henry Jellett, who, buried for years in a remote and obscure country parish, had kept unimpaired his love of theology and his knowledge of books. He was as eloquent as his better-known brother, afterwards Provost of Trinity College, but without the same advantages of voice and personal appearance. A moderate high Churchman, he proved broader and more liberal than some of the professed broad Churchmen. Among these latter the best known and most distinguished was his brother, John Hewitt Jellett, whose tall figure, handsome face, flashing eyes, ringing voice, and impetuous eloquence told well in debate. Unlike him and Dr. Reichel, though their friend and strenuous fellow-revisionist, the Rev. the Hon. William Conyngham Plunket, grandson of the great Lord Plunket, and destined himself to succeed to that title, afterwards Archbishop of Dublin, never marred the earnestness of debate by a word that could offend. He desired a compromise which would, if possible, retain all within the National Church. That it was the National Church was his pride and happiness, for the love of country and of Church burned equally in his bosom. His statue stands in an open space in Dublin (near the great educational institution which he reared to train teachers for the schools of the Church), unique as that of a Protestant archbishop whose patriotism and Christian philanthropy were recognized alike 
by Protestant and Roman Catholic. All who knew him loved him.

Of the legal members of the synod the first places were held by Judge Longfield and Dr. Ball, who frequently acted as assessors, assisted by Sir Joseph Napier, sometime member for the University of Dublin. Their voices were for moderation, and it is probable that the warning given by them and by Judge Warren, that to interfere with the ordinal might throw a doubt upon the validity of Irish orders, went far to prevent the change desired by Dr. Reichel and Master Brooke. William Brooke, Master of the Court of Chancery, was the most prominent, though not the most learned, of the ultrarevisionists. The uncle of the better-known Stopford Brooke, he was an evangelical of pronounced views, universally respected for his high character and sincere piety. Tall and spare, with pale face and white hair, it was he who precipitated the revision movement by his resolution for appointing a committee to suggest measures to check the introduction and spread of ritualism. Better known, and universally respected and trusted, was George Salmon, D.D., Regius Professor of Divinity, and afterwards Provost of Trinity, whose attainments in Mathematics, as well as his Introduction to the New Testament and his work on the Infallibility of the Church, earned him a reputation far beyond the country of his birth. Absolutely sincere and straightforward, his learning and moderation gained from the synod an extraordinary trust and affection. His somewhat homely speech was enlivened with a touch of humour, while his strong common-sense amounted at times to genius.

None who knew him can forget the "witty Dean," Hercules Henry Dickinson, the friend and disciple of Archbishop Whately, and the best representative of the more tolerant broad Church party, whose keen sense of the ridiculous enlivened the discussions, and often restored good humour to a heated debate. On the conservative side there was no more acute and well-trained intellect 
than that of J. G. Scott, afterwards Archdeacon of Dublin, whose labours in the synod, in the Representative Church Body, in the organization of the diocese of Dublin, and as a parochial clergyman, deserved a 'much higher recognition than they ever obtained.

Military men who affect the study of theology generally become strong partizans, and the synod was not without a sprinkling of these in the ranks of the ultrarevisionists. The two best equipped for debate were Colonel Ffolliott and Colonel Saunderson. As the revision debates went on the remarkable educational value of free discussion could be noticed in the case of the former. The same could scarcely be said for Colonel Saunderson, who was always a partizan, and who might have been called the Rupert of the revision conflict. His dapper figure, and slashing speech seasoned with abundant wit and humour, made him as conspicuous among the revisionists of the synod as he was among the Unionists in Parliament. In both places he was noted as a hard hitter, a splendid fighting man, without a particle of malice. And when not busy in synod or in Parliament, he was found acceptable by many as a lay preacher.

\section{THE CANONS AND CONSTITUTIONS OF THE CHURCH.}

While the members of the Revision Committee were considering what changes in the rubrics and services should be recommended, the General Synod undertook to draw up canons and constitutions for the Church. Many of these bore upon the subjects under discussion in the revision of the Prayer Book, though others were merely re-enactments of canons already existing.

The constitutions and canons are fifty-four in number, and to these the synod appended the thirtieth English canon on the use of the sign of the cross. It is unnecessary to notice these in detail, and the following brief summary contains all that is needed for our purpose.

The first and second canons prescribe the use of the Irish Book of Common Prayer and the Ordinal. 
The fourth canon forbids to add or diminish anything in its matter or form. It also, in conjunction with canons $34-37$, takes the place of the ornaments rubric in the old Prayer Book. It orders the archbishops and bishops to use the customary apparel of their order, and for presbyters and deacons appoints a plain white surplice, with the customary scarf of black silk and the hood of their degree, with permission to wear bands, and a plain black gown when preaching, a use now almost obsolete.

The fifth canon forbids the minister to turn his back to the congregation when offering up prayer, and orders him when saying the prayer of consecration to stand at the north side or end of the Holy Table, forbids the sign of the cross save when ordered, forbids the act of bowing to the Holy Table or to anything there or thereon, and also the ringing of a bell during divine service. The minister is to speak in a distinct and audible voice, and turn himself so that the people may hear him.

Canon I 5 orders the celebration of the Holy Communion in every church at least once a month, and also on days for which a proper preface is provided.

Canons 34-39 prescribe a moveable Holy Table of wood, and forbid lights (save when needed for giving light) ; they forbid the use of a cross or crucifix on the Holy Table or its covering, or on any structure behind it ; they also forbid elevation, the use of incense, the mixed chalice, wafer bread, and all acts, words, ornaments, or ceremonies other than those prescribed in the Prayer Book. They also forbid the carrying of any cross, banner, or picture through church or churchyard in any religious ceremony.

Canon 40 orders that no change shall be made in the structure, ornaments, or monuments in any church unless with consent of the select vestry and the approval of the ordinary.

Most of these canons had been suggested by Master Brooke's committee and were intended to prevent the introduction of ritualism. The one that gave most offence to men of moderate minds was that which forbade the use of a cross on or behind the Holy Table. This prohibition was felt as a slight and insult to Him who carried the cross to Calvary ; and gave grievous pain to many pious people who resented it as such, and who felt that it reflected disgrace upon the Church which enacted it. As for the other canons, if they imposed a 
service bare and stripped of many accessories innocent in themselves and intended to add dignity and beauty to Divine service, the extremes to which the ritualistic party in England carried their practices, must bear great part of the blame.

\section{CHANGES MADE IN THE PROCESS OF REVISION.}

The report of the Revision Committee was presented to the synod in two portions, the first in 1872 , the second in 1873 , and the discussion of it occupied the synods of I872-8. It did not contain the new preface which grew out of the final refusal to make certain changes in the formularies ; this was added subsequently. The revised Prayer Book was ordered for use on Ist January, I879.

A number of clergy having protested (under the Church Act) against being bound by any alterations made in the Prayer Book or canons, it was decided at the close of the revision not to make distinction between those who had thus protected themselves and those who had not, unless these latter had obtained promotion or change on faith of a declaration of subscription. This provision was both fair and politic.

The main interest of the revision centred round a. few points-(I) The Athanasian Creed; (2) The Communion Office and the Black Rubric; (3) The Baptismal Service; (4) The Office for the Visitation of the Sick; (5) The Ordinal.

Three modes of revision were attempted. The first by direct alteration of the text; the second by interpretative rubrics; the third by alternative forms. None of these were ultimately approved of, and in the end, on the points chiefly in dispute, recourse was had to a new preface which was to explain " why certain things have been altered and others retained."

The limits of space at our disposal forbid us to notice more than the chief alterations made in the rubrics and services. This we do in the order in which they occur in the Prayer Book. 


\section{Lectionary, Eัc.}

The lectionary follows generally that adopted by the Church of England, but omits all the lessons from the Apocrypha, and includes the whole of the Apocalypse.

The black-letter days are omitted.

The ornaments rubric is omitted, its place having been supplied by ritual canons.

The three sentences after the preface concerning the service of the Church are omitted.

The archbishops and bishops are given authority to appoint days of humiliation and of thanksgiving, and to prescribe special services for the same.

In the rubric before the Te Deum, after the word "minister" there is inserted "or other fit person appointed by him "- a change approved by the Convocation of Canterbury, 1909. This permits laymen to read the lessons.

In the rubrics before Morning Prayer permission is given on certain occasions to shorten the services by omission of parts, and to vary them, and for their use separately or in combination.

Such permission adds considerably to the adaptability of the services, but excludes any change in the Sunday services, and might with advantage have been carried considerably further, especially in order to avoid repetitions.

An additional collect is provided alternative to "Lighten our darkness" in the Evening Prayer.

\section{The Athanasian Creed.}

The question of the Athanasian Creed was one of the chief points on which the interest of the discussion on revision centred. It proved very difficult to deal with. A few would have omitted it entirely, as is done in the American Prayer Book, but, regarding it as a creed, others were unwilling to allow it to be touched at all, although the Greek Church objected to the Filioque clause. On the other hand many would not admit that the damnatory clauses could be in 
any sense part of a creed, and they regarded them with invincible dislike as giving an untrue impression of the character of God. Others again objected to the creed itself as dogmatizing on subjects beyond the faculty of man to understand.

Archbishop Trench endeavoured to obviate the difficulty of the damnatory clauses by softening their absolute statement thus:-in verses 2 and 42 , "Which faith it behoveth everyone to keep whole and undefiled," and "This is the Catholic faith which it behoveth everyone, etc." The suggestion was rejected, not only because it altered the text, but as meaningless and weak.

Others proposed that the use of the creed in public worship should be enjoined upon one day only in the year; that it should be left optional with the priest; or even that the priest alone should read or sing it. Another suggestion was to omit the minatory clauses when the creed was read in public worship, and append a note to Article VIII. to the effect that they formed no part of the creed proper. Again, it was proposed to place it after the XXXIX. Articles, with a note explaining that " the condemnatory clauses are to be taken as referring only to those who, possessing the means and opportunity of knowledge, reject the substance of the Christian Faith." The subject of a new translation was mooted, but it was seen that this could not meet the objections to the creed.

As the explanatory rubric or note failed to satisfy those who objected to the obnoxious clauses, and as the proposal to recite the creed without them was met by an outcry against " mutilating a creed," it was resolved after long discussion to leave the creed in its old place, but to omit the rubric ordering it to be recited, though it was not forbidden for use as an anthem by any so disposed.

It was resolved, however, to insert the following paragraph as to the creed in the new preface:-

"With reference to the Athanasian Creed (commonly so called), we have removed the rubric directing its use 
on certain days; but in so doing this Church hath not withdrawn its witness as expressed in the Articles of Religion, and here again renewed, as to the truth of the Articles of the Christian faith therein contained."

As the creed was left in its place, this statement was weak and unnecessary. The removal of the rubric was, however, perhaps the best solution possible. It was better than the removal of the creed, and far better than the permissive use of it recommended by the Committee of the Convocation of Canterbury in 1909. The creed remains in our Prayer Book as a witness to the doctrine of the Trinity, and for use in teaching, and the compulsory use of clauses which gave offence to many pious people was avoided.

The committee of the Lambeth Conference of 1908 distinctly recognized the right of the several Churches of the Anglican Communion to decide for themselves as to the use or disuse of the creed. The decision of the Church of Ireland was thus justified, although at the time it was made a reproach against her in England, where, if she proposed to omit the damnatory clauses, she was said to " mutilate a creed," while when she kept it unaltered but omitted its public use in the Church service she was told she as good as " denied the Faith."

\section{The Litany.}

A rubric was introduced which regulates the use of the Litany as a separate service, and also in combination with the Communion Office. Permission is given to ask the prayers of the Church for sick and afflicted persons.

It was proposed to introduce suffrages for the royal forces, for the Lord Lieutenant, for the Jews, and for those engaged in missions to the heathen. The rejection of these was a loss.

Prayers and Thanksgivings upon several occasions.

Eight prayers were here introduced-(I) for unity, taken from the service for the 2oth of June (2) in time of any common plague or sickness, instead of the old 
one; (3) for a sick person; (4) for the Rogation Days; (5) for New Year's Day; (6) for Christian missions; (7) for the General Synod; (8) for use in colleges and schools. The committee of the Lambeth Conference speaks of the "urgent need" of similar enrichment in the English Prayer Book.

It may be said generally of all the new prayers that, though their intention is admirable, and their introduction a step in the right direction, their composition is faulty, and their rhythm defective.

It was proposed to omit from the prayer in time of war and tumults the words " abate their pride, assuage their malice, and confound their devices," but unfortunately this was rejected.

The thanksgivings for fair weather and for peace were altered and improved, and one for recovery from sickness was introduced.

\section{The Collects, Epistles, and Gospels.}

Several rubrics were added regulating the use of the collects, epistles, and gospels on various days.

Alternative collects with epistles and gospels are provided for the first celebrations at Christmas and Easter, both collects being taken from the Sarum use.

For the epistle for the first Sunday after Easter (about the three Witnesses) another is substituted, taken from I Corinthians v. 6.

\section{The Psalter.}

Permission is given to substitute other psalms than those in the usual course, on occasions approved by the ordinary, but selections of psalms on the American plan are much needed.

\section{The Holy Communion.}

The obsolete rubric directing intending communicants to give notice to the minister is retained.

Instead of the old rubric requiring communion at least three times in the year, ministers are directed to exhort their people to communicate frequently, and to con- 
tribute regularly to the maintenance of the worship of God. This, with the Canon directing the celebration of the Communion at least once in every month, is a notable attempt to restore the sacrament to its proper place.

The rubric about those living in open and notorious sin is somewhat altered, and in every case the minister is to refer to the disciplinary canon.

It was proposed to permit our Lord's summary of the two tables of the law to be used instead of the ten commandments, as in the Scottish and American Churches: but this was rejected.

The introduction of the verses usually said or sung before and after the Gospel is authorized.

When there is no communion the prayer for the Church militant may be omitted, and on occasions sanctioned by the ordinary the service may begin with the collect, epistle, and gospel.

The two offertory sentences from the Book of Tobit are omitted.

In the first exhortation "damnation" is changed to " condemnation," and it was proposed to omit all the words with reference to Judas after " come not to that holy sacrament" down to "soul," but this was not carried.

In the third exhortation the words "we eat and drink our own damnation " down to " sundry kinds of death" were changed to "we eat and drink judgement to ourselves."

This exhortation may be omitted with consent of the ordinary, provided it be read once in the month at least. This relaxation of the old rubric has since been approved by the Lambeth Conference of 1908.

A new rubric gives those who do not intend to communicate an opportunity to withdraw.

The Sanctus is printed as a separate paragraph. The Committee of the Canterbury Convocation suggests this also.

1. A new rubric allows the words of delivery to be said 
once to as many as shall kneel together to receive the Holy Communion, provided that they shall be said separately to any communicant so desiring it. The proposal of the committee of the Convocation of Canterbury is better than this.

To the rubric before the prayer of consecration the words "standing at the north side of the table" were added. This was equivalent to the " north end," and was by some supposed to do away with the idea of a sacrifice in the Holy Communion, which was thought to be implied by the eastward position, though Archbishop Laud objected to the north end only as being too narrow to hold the Service Book, or to place the bread and wine within the minister's reach.

A proposal was made by the Bishop of Killaloe to change the structure of the prayer of consecration by transposition of some of the words. He wished also to place the Lord's Prayer before the reception, but neither suggestion was carried out. It is possible that he felt that the remodelling this part of the service after the Scottish office was at the time inopportune, though he probably desired it.

Two collects, one slightly altered, taken from the revised office for the burial of the dead, and one from the ordering of priests are added to those at the end of the communion office. This last addition, as "a brief commemoration of the faithful in Paradise," is specially commended by the committee of the Lambeth Conference.

The last collect is converted into one for use after a collection when the prayer for the Church militant is not read.

The rubrics at the end of the office are slightly changed.

\section{The Black Rubric.}

This rubric was intended to exclude the adoration of the elements, and the doctrine of a corporal presence of 
Christ's natural body and blood; "the former it branded as idolatrous, the latter as physically impossible and absurd." It went no further. The ultra-revisionists desired to make an addition which should prohibit all eucharistic adoration. This was attempted in resolutions of various forms.

I. One declared that " no presence of Christ, or of Christ's body and blood, is in the elements after, or by virtue of consecration." This was rejected because in the first instance it involved a denial of His omnipresence, and in the second place it seemed to imply a presence which was not in virtue of consecration, and thirdly, it left it open to teach that, though not in the elements, Christ's body and blood are along with them.

2. A second proposed to declare that "the Church doth not allow eucharistic adoration on any ground whatever." Independently of the ambiguity of the phrase, "eucharistic adoration," it was seen that it was impossible to forbid more than "outward acts and gestures" which had been already done in the canons.

3. Another proposal took the form of a declaration that the Church of Ireland did not "permit it to be taught that by reason of consecration there is in or under the forms of the elements, a presence of Christ, or of Christ's flesh and blood unto which adoration may be or ought to be done." It was objected to this that it would give an impulse to the teaching of the real presence in the form advocated by Freeman, viz., that Christ in His body and blood is really present for participation, though not for adoration. On the other hand, as already observed, a denial of a presence by virtue of consecration, i.e. by virtue of words or manual acts, would not exclude belief in a presence in or under the elements by the agency of the Holy Ghost or in fulfilment of Christ's promise, to which special presence worship would be due.

These additions to the black rubric being rejectsd, it

\footnotetext{
${ }^{1}$ Censor Recensus : a pamphlet by J. F. Meade (a laymas of the Diocese of Glendalough).
} 
was sought to prohibit the teaching of any presence of the body and blood of Christ other than a presence " in the soul of the faithful receiver," but this was not accepted.

All proposed additions to the black rubric having been rejected, two paragraphs were inserted in the new preface and the rubric was left unaltered:-

"As concerning the Holy Communion some of our brethren were at first earnest that we should remove from the Prayer Book certain expressions which they thought seem to lend some pretext for the teaching of doctrine, concerning the presence of Christ in that sacrament, repugnant to that set forth in the Articles of Religion, wherein it is expressly declared that the body of Christ is given, taken, and eaten in the supper only after an heavenly and spiritual manner, and that the mean whereby it is received and eaten is faith; but upon a full and impartial review we have not found in the formularies any just warrant for such teaching, and therefore in this behalf we have made no other change than to add to the Catechism one question with an answer taken out of the 28th of the said Articles.

"As for the error of those who have taught that Christ has given Himself, or His body and blood, in this sacrament to be reserved, carried about, or worshipped, under the veils of bread and wine, we have already in the canons prohibited such acts and gestures as might be grounded on it, or lead thereto : and it is sufficiently implied in the note at the end of the Communion Office (and we now afresh declare) that the posture of kneeling prescribed unto all communicants, is not appointed for any such purpose of adoration."

This declaration closed a controversy most painful to pious minds. In a roundabout way it declared that no change had been made or was necessary, either in the Communion Service or in the black rubric. It was a sort of apology for having changed nothing. Adoration to Christ present is not, and could not be prohibited, for adoration does not consist in outward words, acts, or gestures, its seat is in the heart, its act is the act of faith.

Public Baptism of Infants.

Parents are allowed to be sponsors for their own 
children, and where more cannot be had one sponsor suffices.

The Baptismal Office was practically unchanged by the revision, but the controversy over it was long and bitter for several years. The efforts of the extreme revisionists were directed in the first place towards getting rid of the words "regenerate" and "regeneration" as applied to every child baptized. In the next place, failing that, they sought to obtain a distinct recognition of the lawfulness of the interpretation which applied these words to all on what was called a "charitable hypothesis." In this they were successful.

The wording of the first address was slightly changed by the substitution of one text of St. John for another.

It was proposed to adopt this form for the declaration after baptism :- "Seeing now that this child hath received the sacrament of regeneration," instead of "Seeing now that this child is regenerate." Another proposal was to permit the use of an alternative form at the discretion of the minister. Others suggested that all dogmatic statements as to the effect of baptism should be omitted. Archbishop Trench proposed an explanatory rubric to the effect that "spiritual regeneration doth not exclude the necessity of conversion to God." The proposal, however, which for a time met with most favour was for a new rubric, thus expressed:-

"The language used to describe the grace of baptism expresses the privilege and responsibility of all who receive that sacrament, but in so far as it describes a further grace, the Church of Ireland does not require her members to interpret it as determining that such grace is received by all who receive baptism, or that they who receive that grace do of necessity receive it at the time of the administration of that holy ordinance."

This proposed rubric was at once interpreted in quite opposite ways by the critics. One said that it was "a most unbelieving rubric," and reduced baptism to a mere beggared rite, " an unblest sacrament devoid of all 
operative grace, a mere form of religious registration.", On the other hand, an acute critic, after an exhaustive analysis, declared:

"It precludes no particular views. The same men will continue to teach the same doctrines which they have hitherto taught. Only the new declaration will furnish new texts for conflicting interpretation, and offer new weapons for mutual accusations of unfaithfulness to the teaching of the Church.",

Judge Warren, who at first supported this rubric, afterwards expressed his opinion that it would make the charitable hypothesis (for which low Churchmen contended) more difficult than before.

The difficulty was arranged, we cannot say solved, in a way suggested by the judge, viz., by recognizing the liberty of interpretation already existing, and a clause to effect this was added to the new preface :-

"In the formularies relating to baptism we have made no substantial change. . . At the same time we desire fully to recognize the liberty of expounding these formularies hitherto allowed by the general practice of the Church, and as concerning those points whereupon such liberty has been allowed, we hereby further declare that no minister of this Church is required to hold or teach any doctrine which has not clearly been determined by the Articles of Religion."

No material change was made in the other baptismal formularies. But it would have been an improvement in the office of private baptism if the third question had been more plainly put, thus-Was this child baptized with water?

\section{The Catechism.}

A new question, and an answer, taken from Article XXVIII. are added :

$Q$. After what manner are the body and blood of Christ taken and received in the Lord's supper?

$A$. Only after a heavenly and spiritual manner, and the mean whereby they are taken and received is faith.

\section{Confirmation.}

An alternative to the last collect is provided, and a

¿Censor Recensus, by J. F. Meade, p. 20.

p. 12.

Brief Forecasts, by J. G. Scott (afterwards Archdeacon of Dublin), 
new and rather feeble rubric added instead of the old one:-

" Every person ought to present himself for confirmation (unless prevented by some urgent cause) before he partakes of the Lord's Supper."

The formal presentation of the candidates to the bishop adopted in the American Prayer Book was not ordered, and indeed does not seem to have been proposed. It would have been a distinct improvement.

\section{Solemnization of Matrimony.}

A new rubric is inserted about the publication of banns.

In the opening address the words, "to satisfy men's carnal lusts and appetites," are omitted, and a change (approved by the Lambeth Conference of 1908) is made in the expression of the causes for which marriage was ordained ; but Mr. Frere is in error in stating that our revision followed the American Prayer Book here. The form of the prayer for children is altered somewhat. The Committee of the Convocation of Canterbury recommends both these changes.

The concluding address, which might well have been revised, is made optional, but ends as before with " amazement." An additional collect follows, and after this, if there be no Communion, the "Grace" concludes the office.

\section{The Visitation of the Sick.}

Instead of the rubric enjoining the minister to move the sick person to make a special confession of his sins, a new rubric appoints the use of the precatory form of absolution, taken from the communion office. The minister is, however, not restrained from edifying and comforting the sick "as he shall think meet and convenient," nor is his use of the indicative form prohibited.

Probably no question in the revision was more earnestly debated than this, owing to the fear of anything approaching the Roman doctrine and practice. It was urged against the indicative form of absolution that 
it seemed to arrogate to the priest a power of forgiving sins belonging to God alone, and that the more ancient forms were precatory. In the end the form from the communion office was adopted, and a paragraph in the new preface thus dealt with the matter :-

"The special absolution in the office for the visitation of the sick has been the cause of offence to many : and as it is a form unknown to the Church in ancient times, and as we saw no adequate reason for its retention, and no ground for asserting that its removal would make any change in the doctrine of the Church, we have deemed it fitting that in the special cases contemplated in this office, and in that for the visitation of prisoners, absolution should be pronounced to penitents in the form appointed for the Holy Communion."

Although the change in the form of absolution was made a reproach against the Church of Ireland by many people in England, it has been recommended as an alternative by the Committee of the Convocation of Canterbury in 1909. In the American Prayer Book a form of absolution had been altogether dropped, but strange to say, English Churchmen had no difficulty in condoning that.

\section{The Churching of Women.}

A benediction was added to this office.

\section{A Commination.}

The reference to a restoration of the ancient discipline was omitted from the first exhortation, but otherwise no change of any importance was made in this office, though some were suggested, and are greatly to be desired.

\section{Forms of Prayer at Sea.}

No change of importance was made in this office, or in that for the Communion of the Sick.

\section{The Order for the Burial of the Dead.}

An improved rubric takes the place of the old one, and besides stating more clearly the cases in which the office is not to be used, allows a short service in certain 
special cases, and notably for unbaptized infants, which removes a grave defect of the former office.

An alternative and shorter lesson (I Thess. iv. 13) is provided. In King Edward's first Prayer Book this was the epistle from the Sarum use.

The form of thanksgiving is changed thus: "We bless Thy holy name for all Thy servants departed this life in Thy faith and fear."

\section{The Ordinal.}

No change of any import took place; but a strong effort was made to alter the words, "Receive the Holy Ghost . . . whose sins thou dost remit, etc."

It was proposed that this form should be changed to : - "Almighty God, our Heavenly Father, grant unto thee the gift of the Holy Ghost for the work of a priest in the Church of God," or, at least that these words should be admitted as an alternative form. This was urged by many revisionists who desired to get rid of anything that, as they thought, tended to exalt the office of the priesthood, and to favour the practice of auricular confession. Dr. Reichel, who was their champion, had previously advocated the omission of any form of absolution from the office for the visitation of the sick. He thought he had discovered that the words " Receive the Holy Ghost" had been retained by the English reformers through ignorance of the fact that they were not essential to ordination, and because they feared that their omission would invalidate it. $\mathrm{He}$ was ably and conclusively answered by the Rev. R. Travers Smith, who showed that the English reformers had all necessary information as to the essentials of ordination; that they knew that the words were not necessary; and that whereas Dr. Reichel had referred to Archbishop Whitgift as having asserted that the English ordinal was taken word for word from the Roman Pontifical, the opposite was the case, the charge having been made by Cartwright and strongly repudiated by Whitgift. He showed also that the Roman doctrine of confession and 
absolution in no way depends on the use of the words "Receive the Holy Ghost," which are not by the Roman Church regarded as essential to ordination, inasmuch as. in the Roman Pontifical the candidates are called " ordinati " and allowed to perform the special functions of priests before those words occur in the office.

The ordinal controversy was not settled till 1877 , when, instead of making a change in the words, a long paragraph was inserted in the new preface as follows:-

"No change has been made in the formula of ordination of priests ; for upon a full review of our formularies we deem it plain, and here declare, that, save in the matter of ecclesiastical censures, no power of authority is by them ascribed to the Church or to any of its. ministers, in respect of the forgiveness of sins after baptism, other than that of declaring and pronouncing on God's part, remission of sins to all that are truly penitent, to the quieting of their conscience, and removal of all doubt and scruples: nor is it anywhere in our formularies taught or implied, that confession to, and absolution by a priest are any conditions of God's pardon, but on the contrary it is fully taught that all Christians may draw nigh as worthy communicants to the Lord's table without any such confession or absolution."

In this, as in other paragraphs of the new preface, the defensive or apologetic tone adopted gives an impression of weakness prejudicial to the authority with which the formal documents of a Church should speak. They were intended to conciliate disappointed revisionists, and perhaps that is the best excuse that can be made for them.

The form of prayer on the day of a sovereign's accession was only changed in some unimportant respects.

\section{New Offices.}

Four new forms of prayer were added:-

I. For the first Sunday in which a minister officiates. in the church of a cure to which he has been instituted.

2. For harvest thanksgiving.

3. For the consecration of a church. 
4. For the consecration of a burial ground.

These form a real enrichment to our offices.

The Revised Prayer Book also contains:-

The articles of religion approved by the synod of Dublin in 1634 ; these are identical with the English Articles of 1571 .

The table of kindred and affinity.

The preamble and declaration adopted by the General Convention in 1870 .

The constitution and canons ecclesiastical as agreed to by the General Synods held in Dublin, 1871-9, with the thirtieth English canon appended.

THE CHURCH OF ENGLAND AND THE DISESTABLISHED CHURCH OF IRELAND.

The story of the revision would not be complete without some notice of the attitude of the Church of England towards her sister Church in that hour of trial.

It is not a noble or inspiring theme-not a story worthy of an ancient and powerful Church with splendid traditions. Let us not linger long over it. The attitude of the English Church was determined by the high Church party. We have already said that the word Protestant was abhorrent to high Churchmen, and more especially to the ritualistic party. Many of them, though they recognized the American and Colonial Churches, in which the lay element was prominent, with strange inconsistency were shocked that the same element in the Church of Ireland should lay claim to similar rights, though the whole episcopate of the Anglican Communion was agreed as to the lawful position of the laity in Church synods. No doubt this was in part due to the extraordinary conservatism of the English character, which can scarcely bear to give up an old custom even in order to do away with a manifest abuse.

They did not remember that what they termed Churchmanship was of comparatively recent revival in the Church of England itself, and that if it was at a low ebb here it was owing to two things-(I) the fact that 
Irish Protestants were face to face with an aggressive Romanism which had identified itself with an actively hostile political organization ; (2) that for centuries the Irish Church had been ruled by bishops reared in England who came over to Ireland to enrich themselves and their families, and whose object, even when they were respectable, was to maintain the English interest rather than to advance the good of the Church. Ignorant of the injuries inflicted on the Irish Church by this policy of English statesmen, they judged her harshly and unsparingly.

There were no English Churchmen for whom Archbishop Trench had so deep a feeling of respect and friendship as Dr. Pusey, Canon Liddon, and Wilberforce, the Bishop of Oxford. To them he turned in critical moments, for he was profoundly attached to the English Church, and sensitive to the opinion of her leaders. But it cannot be said that he received wise advice in his difficulties. They were afraid of the laity. The two former at least were persuaded that heresy must result if laymen were admitted to Church synods; they abhorred the idea that the laity might discuss and vote on matters connected with doctrine. This thorough distrust prejudiced their view of the Irish Church, and Irish Churchmen who strove to avert disaster received scant sympathy at their hands.

It may be admitted that many of the proposals, and some of the acts of the General Synod were unwise, and tinged by a narrow party spirit. Some of the canons, and more especially that concerning the cross, could not but be most repugnant to English, as to many Irish Churchmen. But nevertheless English critics might have seen - they ought to have seen-in the gathering of numbers of laymen year after year from distant places at personal inconvenience and expense, and in the earnest debate, and the deep interest they took in things with which they had been unfamiliar, a great element of hope for the future, and signs of a life more real than could have been manifested by a mere passive 
acquiescence in things as they were. Above all, they might have had faith, and not have hastily concluded that all that was threatened was already lost.

Unfortunately while the matter was still in debate, and the event could not be predicted, Dr. Pusey assumed that the Church of Ireland was about to become heretical, and presumed to advise the bishops, clergy, and laity what they should do in that event:

"If either of these rubrics were carried, I should, were I an Irish clergyman, betake myself to England, thinking the Irish Church heretical. . . ; were I a layman with property, I should sell my property and go to England."

When we consider that there was a very considerable body both of clergy and laymen in the Irish Church opposed to the rubrics which he condemned, and that the existing clergy were expressly protected by the Church Act from being compelled to agree to any change of doctrine, and were free to remain at their posts and maintain their witness to the truth, such advice to abandon at once all effort and hope and to seek comfort and ease in England, must appear faithless in the extreme. Athanasius would not so have acted or advised.

The truth is that the English high Church party was incapable of understanding the position of affairs after the disestablishment. It dreamed, at least Canon Liddon who might be taken to represent it did, so late as 1875 , that the Church might have gone on without lay representation :

"The greatest mistake," he wrote, "was the substitution of the anomalous synod for the ancient convocations. . . . Are not the old convocations only dormant? Could they not be summoned by the archbishops? Would they not at once speak with an authority which this singular collection of clergymen, colonels, and lawyers, can never command when undertaking to deal with the truths of Divine revelation however indirectly?"

One does not know whether to wonder most at his 
total misconception of the circumstances of a disestab. lished Church, or at the singular ignorance of human nature betrayed by such remarks. Dr. Pusey also thought that the " clock could be put back."

"Your Grace," he wrote to Archbishop Trench, "with the Bishop of Derry and the Archbishop of Armagh, have the immediate future of the Church of Ireland in your own hands, you have but to say, 'In v:ew of all these evils which changes will produce we will have nothing to do with the changes, or with the body which makes them.' They would be dropped."

When it was proposed to omit the damnatory clauses from the Athanasian Creed, but to recite the rest of it in public worship, Dr. Pusey declared that such a course

" leaves everything as a mere matter of private opinion, except what the Arians and semi-Arians might have held on the one side, and tritheists on the other. It leaves out 'the right faith is' even as to the Incarnation of our Lord Jesus Christ. . . It excludes the necessity of believing the three persons to be God and Lord in any special sense. . . It makes everyone the judge as to his own faith."'1

It came to this that in Dr. Pusey's view, no creed was worth anything without an anathema, and the fact was ignored that this so-called Arian creed was placed in the same book with, and to be interpreted by that of Nicaea. All this time they were in full communion with the American Church, which had wholly expunged the Athanasian creed from the Prayer Book.

Equally unfair was Pusey's comment on the change of the absolution in the visitation of the sick. In one breath he admitted that the precatory form is as valid as the indicative; in another he declared that its use " tacitly effaced the office of the priest." Here, again, he ignored the fact that the American Church had wholly abolished the absolution in that office.

Nobody would now assert that the original draft of the new preface, nor indeed the final form, was a satisfactory

${ }^{1}$ Letters and Memorials of Archbishop Trench, ii. 199. 
document. Its authors admitted as much by the changes they made in it. But even as it stood at first it was a practical acknowledgement by the ultra-revisionists that their attack on the Prayer Book had failed, that they had not been able to change any of the doctrines to which they had objected, nor even to change the language in which they were expressed. The most they had obtained was the acknowledgement of a certain liberty of interpretation which had existed before, and which was recognized by law in England itself.

One would think, in reading Dr. Pusey, that in the Church of England there did not exist, and never had existed, on what he called vital doctrines, any differences of opinion and interpretation. The truth was the very opposite of this. The liberty claimed in Ireland had been claimed and allowed in England. The opinions he objected to were as strongly held and as fully preached in the Church of England as in that of Ireland. If the Church of England had "been at one with herself," Dr. Pusey's reproaches might have had some force, but, as it was, the revisers might have retorted on him, "Physician, heal thyself. If this liberty is falsifying the truth in Ireland, is it not just as much so in England?"

But disapproval went much further than this sort of criticism. It went so far that Dr. Pusey and Canon Liddon, who might be taken as representing, not the extreme ritualists, but the sound and sober high Churchmen, wrote "offering large subscriptions" towards building a church in Dublin, " if it could be arranged that, as in many Scottish churches, only the unaltered English Prayer Book should be used in it." 1 It is difficult to characterize such a proposal without using language that might sound unduly strong. In making it they went directly in the face of their own principles, according to which such churches were unlawful intrusions into the dioceses of the Episcopal Church of Scotland, with which the Church of England was in full

\footnotetext{
${ }^{1}$ See Life of Archbishop Trench, ii. 197.
} 
communion. Low Churchmen might not be scandalized by such a proposal; it might not even have surprised us if the extreme ritualists attempted to justify it, but for high Churchmen to do so was to renounce their own cherished principles. Here were two simple presbyters of the Church of England, of their own mere motion, without sanction of archbishop or synod, or even consulting them, planning to foster with their money a schism in a Church with which their own Church was still in communion. ${ }^{1}$ That such a schism in the struggling Church was not begun and established, with evils that none now can calculate, was due, not to their Christian charity, or care for Church order, but to the saner judgement, and more truly Catholic principles of the Archbishop of Dublin.

But enough, and perhaps more than enough, has been said on this. The bitterness is past, though something of regret must linger still. If the Church of Ireland was not altogether wise in the new and untried task that was set her, she has at least the satisfaction of perceiving that her severe critics have in many points not been too proud to follow her example. If she were taunted with desiring the "mutilation of a creed" by proposing the omission of the damnatory clauses of the Athanasian Creed, and for " denying the Faith" in omitting its use in public worship, she may point to the unanimous voice of the bishops of the whole Anglican Communion in the Lambeth Conference of 1908 which has justified her in both respects, pronouncing that as to the use or disuse of this creed "the several Churches may rightly decide for themselves what in their varying circumstances is desirable." She may also call attention to the report of the Committee of Convocation of the Lower House of Canterbury which, in 1909, recommended that the use of the creed should be optional. If, again, she were taunted for having "tacitly effaced the office of the

\footnotetext{
${ }^{1}$ It is to be noted that the biographers of Pusey and Liddon were not proud of this escapade. They do not excuse it; nay, I believe they do not notice it.
} 
priest" by substituting the precatory for the indicative form of absolution in the office for the Visitation of the Sick, she may point to the unanimous recommendations by the same committee that the precatory form should be an alternative. She may also regard with some satisfaction the fact that not a few of the other alterations in rubrics, and readjustments in the services made by her have since been approved and authoritatively recommended for adoption in the Church of England ; and that an English bishop who, unlike most of her critics, has taken the trouble to "make a minute study" of her Prayer Book has been candid enough to confess that such a study has raised it much in his estimation. ${ }^{1}$

\section{CONCLUSION.}

The great and important work of the revision of the Book of Common Prayer undertaken by the Church of Ireland at a critical point in her history-undertaken with much anxiety and many questionings of heart, but yet in humble dependence on the promise of Christ-was brought to an end in 1879 when the revised book was printed and put in use.

That therein some things were done which we might wish undone, and some which might have been better done, was surely to be expected when the Church was suddenly placed in such strange and painful circumstances. That much was left undone which experience has shown to be desirable is a thing comparatively easy to correct. That, upon the whole, many changes that were made have been proved wise and wholesome is a thing to make us rejoice and take courage, with thankfulness to the Divine Spirit without whose help and guidance human wisdom can provide nothing rightly.

It was a wise discretion which guided the Church of Ireland not to call to her councils at this crisis the assistance of liturgical scholars from outside, much as that assistance may have appeared desirable. To have done so would have been to increase the multitude of

${ }^{1}$ Visitation Charge of the Bishop of Salisbury, August, 1909. 
councillors who, however wise and learned, must needs have been ignorant of the peculiar circumstances of the case, and thus to have enlarged the chances of controversy and division at a moment when it was absolutely necessary to reduce these to a minimum.

Thankful must we be to Almighty God that the double danger of a schism in the Church of Ireland, and of separation from the Church of England was avoided, that no change was made which affected doctrine, and that our national Church remained reformed, but no less catholic and apostolic, faithful to the charge committed to her, and free to do her work untrammelled by connexion with the State.

LAUS DEO. 




\section{BX 5536 S53 1910 TRIN}

Sherlock, William, The story of the revision of the Irish prayer book

\section{BX 5536 S53 1910 TRIN} Sherlock, William, The story of the revision of the Irish prayer book 
